\title{
Dendritic cell-based approaches in the fight against
} diseases

\section{Rafael de Freitas e Silva ${ }^{1,2}$, Maria Carolina Accioly Brelaz de Castro ${ }^{2}$ and Valéria Rêgo Alves Pereira ${ }^{2}$}

1 Department of Natural Sciences, University of Pernambuco, Garanhuns, Brazil

2 Department of Immunology, Aggeu Magalhães Research Center, Oswaldo Cruz Foundation, Recife, Brazil

*Correspondence: rafael.silva@upe.br

Edited and reviewed by:

Brian J. Czerniecki, University of Pennsylvania, USA

Keywords: dendritic cells, immunotherapy, vaccine, cancer, infectious diseases

\section{DENDRITIC CELL ROLE IN THE IMIMUNE SYSTEM AND ITS MANIPULATION}

The immune system works to contain infections through activation of different molecules and cell types. Correct presentation of antigens by antigen-presenting cells (APCs) is a critical step necessary to initiate an immune response. APCs have the ability to take-up and process antigens, and express high levels of co-stimulatory and major histocompatibility complex (MHC) molecules bound to antigens (1).

Dendritic cells (DCs) are innate immune cells first characterized and reported by Ralph Steinman in 1973 (2). For their unique properties and features, DCs are the most important APCs acting at the interface of innate and adaptive immunity, which results in the activation of immune responses in the body. Distinct subsets of DCs are associated with lineage and receptor expression patterns (3).

Dendritic cells have different roles in the immune system, such as activation and regulation of adaptive immune responses, and other opposing functions in the induction of tolerance and anergy (4). During immune responses, DCs are crucial decision makers toward the development of naïve $\mathrm{T}$ cells to $\mathrm{T}$ helper type 1 (Th1) or type (Th2) profile (5).

Among the different families of molecules expressed by DC to aid in their function, one of them is the family of toll-like receptors (TLR). TLR which are expressed by different types of DCs, and bind to common molecules associated with pathogens. Once bound, molecules such as bacterial lipopolysaccharide and hypomethylated CpG DNA, can induce activation of biochemical cell pathways, resulting in overexpression of MHC, co-stimulatory molecules (CD80, CD86), and cytokines (6).
In this context, a number of methods have been available to manipulate DCs from diverse sites in the body resulting in activated cells for therapy. These methods include reinfusion of unloaded DCs; reinfusion of DCs co-cultured with peptides or proteins of interest; in vivo DC loading; DC transfection with antigen-encoding viruses or nucleic acids; and DC-derived exosomes $(7,8)$. After this, DCs might be ready to promote protection or treat specific diseases.

In this context, the availability of methods to manipulate DCs in laboratory, arise as an important tool for immunointerventions in different diseases. In this opinion article, we focused on the basis of DC approaches already available in the field of cancer currently in test for infectious diseases, and future interventions that are needed.

\section{DENDRITIC CELL APPROACHES FOR CANCER}

Since initial tests with murine models, activated DCs have been an attractive alternative to treat cancer as an immunostimulatory vaccine. This vaccine has the ability to induce effective cancer immunity by inducing Th1 cells and specific cytotoxic $\mathrm{T}$ lymphocytes to tumor antigens, as well as natural killer (NK) cells $(9,10)$. The potential of anti-cancer vaccines also lies on their capacity to stimulate long-lasting memory $\mathrm{T}$ cells against tumor antigens. Among the subsets of memory $\mathrm{T}$ cells, the presence of central memory $\left(\mathrm{T}_{\mathrm{cm}}\right)$ cells has been associated with a better antitumor function than effector memory cells (11).

The first attempt of vaccination was performed with DCs derived from patients with non-Hodgkin's lymphoma who have failed current treatment. Immunoglobulin idiotype from the patient's tumor were used to load DCs ex vivo and then were reinjected into the patient's body - what resulted in the complete remission of the tumor (12).

To date, many clinical assays employing different methods to activate DCs have been in test for different types of cancers. Most trials were performed using autologous DCs pulsed ex vivo with tumor antigens or derived peptides, and administered to patients with or without chemotherapy or other immune agent (13). However, other types of interventions are in course in clinical trials, such as those using DCs engineered to express tumor antigens with or without molecules such as CD40 ligand, CD70, and TLR-4 $(14,15)$. Important results were shown in one trial performed by Tel et al. (16), who reported a strong immune-specific response against melanoma after administration of a particular subset of DCs, called plasmacytoidDCs (pDCs) pulsed with melanoma specific antigens. pDCs have been seen as interesting players in this task, since once properly activated they are able to produce high levels of gamma-interferon (IFN- $\gamma$ ) and elicit a robust Th1 immune response.

Most clinical assays have used ex vivo manipulation of patient's peripheral blood monocytes cultured in the presence of interleukin (IL)- 4 and recombinant granulocyte macrophage-colony stimulating factor (GM-CSF) to achieve DCs for therapy (17). In this way, a DC-based preparation of autologous cells expanded ex vivo in the presence of a prostatic acid phosphatase/GM-CSF fusion protein (sipuleucel-T, Provenge ${ }^{\circledR}$ ) was approved by the US FDA and other international regulatory agencies for use in patients with advanced metastatic prostate 
cancer (18). From trials initiated in 2012, sipuleucel-T is involved in at least seven trials against prostate cancer, combining sipuleucel-T with: different regimens of radiotherapy (19); administration of monoclonal antibody against cytotoxic $\mathrm{T}$ lymphocyte-associated protein 4 (CTLA4) (20); administration of recombinant human IL-7 (21); and injection of DNAbased anti-cancer vaccine together with GM-CSF (22). Thus, it is expected that further results with sipuleucel-T will be disclosed in the next years.

However, ex vivo manipulation of DCs are limited by some factors, such as the high cost, the long time needed to handled in laboratory, and ultimately the high risk of infection to the patients $(23,24)$. The latter issue is clearly one of the most important, since cancer patients might be already immunocompromised and susceptible to diverse pathogen infections.

To overcome this issue, searching for new alternatives to ex vivo manipulation are in course, and many of them are being developed, such as activation and loading DCs with antigens in vivo. One good example is the use of specific peptides combined with GM-CSF to attract and activate DCs in vivo, which showed prospective clinical results (25). Other strategy is the use of cancer cells genetically modified to express GM-CSF, resulting in the attraction and activation of DCs (26). Another tactic is the delivery of oncolytic viruses, which preferentially infect and kill cancer cells (27).

One of the most promising approaches is the in vivo targeting of specific DC receptors using antibodies coupled with antigens $(28,29)$. It was verified that administration of this type of vaccine with DC activators such as TLR3, TLR-7-8, and CD40 agonists allows the establishment of immunity in diverse diseases settings, including infections [e.g., malaria and human immunodeficiency virus (HIV)] and cancer $(30,31)$.

Although prospective results are disclosed and expected, most clinical trials fail to go beyond Phase II due to a reduced success rate. This indicates that more studies are needed to fill gaps in the comprehension of the immune response necessary to eliminate cancer and explore this knowledge in DC cancer vaccines, such as the use of TLR agonists and the particular role of each DC subset. In parallel, work groups are dedicating efforts to identify better correlates of clinical efficacy to evaluate results from clinical trials more properly.

\section{DENDRITIC CELL APPROACHES FOR INFECTIOUS DISEASES}

Dendritic cell manipulation offers an interesting approach to fight against infectious diseases, and an alternative to prompt a protective immunity, since some treatments are ineffective or inexistent in those $(32,33)$. Previous studies have shown that DCs can induce protection against different pathogens, including protozoan, bacteria, and virus. DCs recognize microorganisms through TLR or C-type lectin receptors $(34,35)$. Vaccination works have reported protection against leishmaniasis (36, 37), Herpes simplex virus $(38,39)$, influenza virus (40), and Candida albicans (41), among other pathogens, such as HIV.

Human immunodeficiency virus has different mechanisms of evasion from the immune system, and nowadays the main source of treatment to infected patients is to follow combination antiretroviral therapy (cART) for life. However, attention was drawn to promising results obtained by the use of DC-based vaccine against HIV. Lu et al. (42) performed the first success clinical trial described, and found a significant reduction in plasma viral load (VL) after administration of autologous DCs loaded with inactivated autologous virus in HIV-1 infected patients. At least 12 studies have achieved interesting results, and evolved to clinical trials with HIV-1 infected patients and reported HIV-1 specific-immunological responses (43). Recently, García et al. (44) observed a significant decrease in VL in HIV1 chronic infected patients who have interrupted cART treated with autologous monocyte-derived DCs pulsed with autologous heat-inactivated whole HIV. Previously, García et al. (45) also showed promising results with significant drop in VL in HIV-1 infected patients off-cART treated with the same vaccine preparation. Based on this, it is expected that in the next few years good results will be achieved, enhancing the chances to develop an immunointervention that could help infected individuals.

Although now it is possible to target vaccine antigens to DCs in $\mathrm{T}$ and
$\mathrm{B}$ areas and to modulate their function with adjuvants, there is still no currently approved DC therapy for infectious diseases, and most experimental approaches are especially with animal models (46). One good example is leishmaniasis, which is one of the most important neglected diseases that cause deaths and morbidity in more than 88 countries. Current human anti-leishmania vaccines available are limited by their inefficiency to confer protection against the different species and also by their safety, which is contested. DCs approaches for leishmaniasis were proposed by different groups of research with remarkable results showing low levels of parasite burden and high levels of Th1 cytokines in animals treated $(47,48)$. However, results from studies with animal models might be difficult to translate the results to humans, and it will remain a goal for further investigations. DCs therapy for leishmaniasis and other infectious diseases would aid mainly refractory patients to current treatments due to high toxic drugs that are available for use or the increasing number of resistant pathogens. Furthermore, immunocompromised individuals, such as those with AIDS or grafted, would be benefited by more safety and effective treatments against different pathogens.

\section{CONCLUSION}

In the last couple of years, DC therapies approaches have been shown to be feasible and secure. Successful results were and are being obtained with cancer patients and animal models. DCs have an extraordinary capacity to orchestrate the host's immune response, which offers new perspectives for the development of vaccines and immunotherapeutic strategies against cancer and infectious diseases among others. However, due to the success that is been observed with cancer and also due to the efforts that is being put by many research groups in the development of antigens and adjuvants with good immunological stimulatory capacities, we believe that in a closer future DC therapies will be also a viable approach to treat and/or prevent infectious diseases.

\section{REFERENCES}

1. Adema GJ. Dendritic cells from bench to bedside and back. Immunol Lett (2009) 122:128-30. doi:10.1016/j.imlet.2008.11.017 
2. Steinman RM, Cohn ZA. Identification of a novel cell type in peripheral lymphoid organs of mice. I. Morphology, quantitation, tissue distribution. J Exp Med (1973) 137:1142-62. doi:10.1084/jem. 137.5.1142

3. Merad M, Sathe P, Helft J, Miller J, Mortha A. The dendritic cell lineage: ontogeny and function of dendritic cells and their subsets in the steady state and the inflamed setting. Annu Rev Immunol (2013) 31(1):563-604. doi:10.1146/ annurev-immunol-020711-074950

4. Pletinckx K, Döhler A, Pavlovic V, Lutz MB. Role of dendritic cell maturity/costimulation for generation, homeostasis, and suppressive activity of regulatory T cells. Front Immunol (2011) 27(2):39. doi:10.3389/fimmu.2011.00039

5. Lutz MB. How quantitative differences in dendritic cell maturation can direct $\mathrm{TH} 1 / \mathrm{TH} 2$-cell polarization. Oncoimmunology (2013) 2(2):e22796. doi:10. 4161/onci.22796

6. Akira S, Takeda K, Kaisho T. Toll-like receptors: critical proteins linking innate and acquired immunity. Nat Immunol (2001) 2:675-80. doi:10. 1038/90609

7. Van Meirvenne S, Straetman L, Heirman C, Dullaers M, De Greef C, Van Tendeloo V, et al. Efficient genetic modification of murine dendritic cells by electroporation with mRNA. Cancer Gene Ther (2002) 9:787-97. doi:10.1038/sj.cgt.7700499

8. You CX, Shi M, Liu Y, Cao M, Luo R, Hermonat PL.AAV2/IL-12 gene delivery into dendritic cells (DC) enhances CTL stimulation above other IL-12 applications: evidence for IL-12 intracrine activity in DC. Oncoimmunology (2012) 1:847-55. doi:10.4161/onci.20504

9. Galluzzi L, Senovilla L, Vacchelli E, Eggermont A, Fridman WH, Galon J, et al. Trial watch: dendritic cell-based interventions for cancer therapy. Oncoimmunology (2012) 1:1111-34. doi:10.4161/ onci. 21494

10. Lion E, Smits EL, Berneman ZN, Van Tendeloo VF. NK cells: key to success of DC-based cancer vaccines? Oncologist (2012) 17:1256-70. doi:10.1634/ theoncologist.2011-0122

11. Ricupito A, Grioni M, Calcinotto A, Bellone M. Boosting anticancer vaccines: too much of a good thing? Oncoimmunology (2013) 2(7):e25032. doi: 10.4161/onci.25032

12. Hsu FJ, Benike C, Fagnoni F, Liles TM, Czerwinski D, Taidi B, et al. Vaccination of patients with B-cell lymphoma using autologous antigenpulsed dendritic cells. Nat Med (1996) 2:52-8. doi:10.1038/nm0196-52

13. Vacchelli E, Vitale I, Eggermont A, Fridman WH, Fucíková J, Cremer I, et al. Trial watch: dendritic cell-based interventions for cancer therapy. Oncoimmunology (2013) 2(10):e25771. doi: 10.4161/onci.25771

14. Morse MA, Niedzwiecki D, Marshall JL, Garrett $\mathrm{C}$, Chang DZ, Aklilu $\mathrm{M}$, et al. A randomized Phase II study of immunization with dendritic cells modified with poxvectors encoding CEA and MUC1 compared with the same poxvectors plus GM-CSF for resected metastatic colorectal cancer. Ann Surg (2013) 258(6):879-86. doi:10.1097/SLA. 0b013e318292919e

15. Iclozan C, Antonia S, Chiappori A, Chen DT, Gabrilovich D. Therapeutic regulation of myeloid-derived suppressor cells and immune response to cancer vaccine in patients with extensive stage small cell lung cancer. Cancer Immunol Immunother (2013) 62:909-18. doi:10. 1007/s00262-013-1396-8

16. Tel J, Aarntzen EH, Baba T, Schreibelt G, Schulte BM, Benitez-Ribas D, et al. Natural human plasmacytoid dendritic cells induce antigen-specific Tcell responses in melanoma patients. Cancer Res (2013) 73:1063-75. doi:10.1158/0008-5472.CAN12-2583

17. Berger TG, Strasser E, Smith R, Carste C, SchulerThurner B, Kaempgen E, et al. Efficient elutriation of monocytes within a closed system (Elutra) for clinical-scale generation of dendritic cells. J Immunol Methods (2005) 298:61-72. doi:10. 1016/j.jim.2005.01.005

18. Kantoff PW, Higano CS, Shore ND, Berger ER, Small EJ, Penson DF, et al. Sipuleucel-T immunotherapy for castration-resistant prostate cancer. N Engl J Med (2010) 363:411-22. doi:10. 1056/NEJMoa1001294

19. Kroemer G, Zitvogel L. Abscopal but desirable: the contribution of immune responses to the efficacy of radiotherapy. Oncoimmunology (2012) 1:407-8. doi:10.4161/onci.20074

20. Ribas A, Comin-Anduix B, Chmielowski B, Jalil J, de la Rocha P, McCannel TA, et al. Dendritic cell vaccination combined with CTLA4 blockade in patients with metastatic melanoma. Clin Cancer Res (2009) 15:6267-76. doi:10.1158/1078-0432. CCR-09-1254

21. Sportès C, Gress RE, Mackall CL. Perspective on potential clinical applications of recombinant human interleukin-7. Ann N Y Acad Sci (2009) 1182:28-38. doi:10.1111/j.1749-6632.2009. 05075. $\mathrm{x}$

22. Alfaro C, Perez-Gracia JL, Suarez N, Rodriguez J, Fernandez de Sanmamed M, Sangro B, et al. Pilot clinical trial of type 1 dendritic cells loaded with autologous tumor lysates combined with GM-CSF, pegylated IFN, and cyclophosphamide for metastatic cancer patients. J Immunol (2011) 187:6130-42. doi:10.4049/jimmunol.1102209

23. Merad M, Sugie T, Engleman EG, Fong L. In vivo manipulation of dendritic cells to induce therapeutic immunity. Blood (2002) 99(5):1676-82. doi:10.1182/blood.V99.5.1676

24. Klechevsky E, Flamar AL, Cao Y, Blanck JP, Liu M, O'Bar A, et al. Cross-priming CD8+ T cells by targeting antigens to human dendritic cells through DCIR. Blood (2010) 116:1685-97. doi:10.1182/ blood-2010-01-264960

25. Walter S, Weinschenk T, Stenzl A, Zdrojowy R, Pluzanska A, Szczylik C, et al. Multipeptide immune response to cancer vaccine IMA901 after single-dose cyclophosphamide associates with longer patient survival. Nat Med (2012) 18(8):1254-61. doi:10.1038/nm.2883

26. Le DT, Pardoll DM, Jaffee EM. Cellular vaccine approaches. Cancer J (2010) 16(4):304-10. doi:10. 1097/PPO.0b013e3181eb33d7

27. Russell SJ, Peng KW, Bell JC. Oncolytic virotherapy. Nat Biotechnol (2012) 30(7):658-70. doi:10. 1038/nbt.2287

28. Bonifaz L, Bonnyay D, Mahnke K, Rivera M, Nussenzweig MC, Steinman RM. Efficient targeting of protein antigen to the dendritic cell receptor DEC-205 in the steady state leads to antigen presentation on major histocompatibility complex class I products and peripheral CD8+ T cell tolerance. J Exp Med (2002) 196(12):1627-38. doi:10.1084/jem.20021598

29. Soares H, Waechter H, Glaichenhaus N, Mougneau E, Yagita H, Mizenina $\mathrm{O}$, et al. A subset of dendritic cells induces CD4+ $\mathrm{T}$ cells to produce IFN-gamma by an IL-12-independent but CD70-dependent mechanism in vivo. $J$ Exp Med (2007) 204(5):1095-106. doi:10.1084/jem. 20070176

30. Tacken PJ, Figdor CG. Targeted antigen delivery and activation of dendritic cells in vivo: steps towards cost effective vaccines. Semin Immunol (2011) 23(1):12-20. doi:10.1016/j.smim.2011.01. 001

31. Steinman RM. Decisions about dendritic cells: past, present, and future. Annu Rev Immunol (2012) 30:1-22. doi:10.1146/annurev-immunol100311- 102839

32. Fajardo-Moser M, Berzel S, Moll H. Mechanisms of dendritic cell-based vaccination against infection. Int J Med Microbiol (2008) 298:11-20. doi:10. 1016/j.ijmm.2007.07.003

33. Delamarre L, Mellman I. Harnessing dendritic cells for immunotherapy. Semin Immunol (2011) 23:2-11. doi:10.1016/j.smim.2011.02.001

34. Moll H. Antigen delivery by dendritic cells. Int $J$ Med Microbiol (2004) 294:337-44. doi:10.1016/j. ijmm.2004.03.003

35. Steinman RM. Dendritic cells in vivo: a key target for a new vaccine science. Immunity (2008) 29:319-24. doi:10.1016/j.immuni.2008.08.001

36. Agallou M, Margaroni M, Karagouni E. Cellular vaccination with bone marrow-derived dendritic cells pulsed with a peptide of Leishmania infantum KMP-11 and CpG oligonucleotides induces protection in a murine model of visceral leishmaniasis. Vaccine (2011) 12:5053-64. doi:10.1016/j.vaccine. 2011.04.089

37. Agallou M, Smirlis D, Soteriadou KP, Karagouni E. Vaccination with Leishmania histone H1-pulsed dendritic cells confers protection in murine visceral leishmaniasis. Vaccine (2012) 20:5086-93. doi:10.1016/j.vaccine.2012.05.075

38. Schön E, Harandi AM, Nordström I, Holmgren J, Eriksson K. Dendritic cell vaccination protects mice against lethality caused by genital herpes simplex virus type 2 infection. J Reprod Immunol (2001) 50:87-104. doi:10.1016/S01650378(00)00094-2

39. Ghasemi M, Erturk M, Buruk K, Sonmez M. Induction of potent protection against acute and latent herpes simplex virus infection in mice vaccinated with dendritic cells. Cytotherapy (2013) 15(3):352-61. doi:10.1016/j.jcyt.2012.11. 012

40. Konduri V, Decker WK, Halpert MM, Gilbert B, Safdar A. Modeling dendritic cell vaccination for influenza prophylaxis: potential applications for niche populations. JInfect Dis (2013) 207:1764-72. doi:10.1093/infdis/jit087

41. Kundu G, Noverr MC. Exposure to host or fungal PGE2 abrogates protection following immunization with Candida-pulsed dendritic cells. Med Mycol (2011) 49:380-94. doi:10.3109/13693786. 2010.532514 
42. Lu W, Arraes LC, Ferreira WT, Andrieu JM. Therapeutic dendritic-cell vaccine for chronic HIV1 infection. Nat Med (2004) 10:1359-65. doi:10. 1038/nm1147

43. García F, Routy JP. Challenges in dendritic cellsbased therapeutic vaccination in HIV-1 infection workshop in dendritic cell-based vaccine clinical trials in HIV-1. Vaccine (2011) 29(38):6454-63. doi:10.1016/j.vaccine.2011.07.043

44. García F, Plana M, Climent N, León A, Gatell JM, Gallart T. Dendritic cell based vaccines for HIV infection: the way ahead. Hum Vaccin Immunother (2013) 9(11):2445-52. doi:10.4161/hv.25876

45. García F, Climent N, Assoumou L, Gil C, González N, Alcamí J, et al. A therapeutic dendritic cell-based vaccine for HIV-1 infection. J Infect Dis (2011) 203(4):473-8. doi:10.1093/ infdis/jiq077
46. Masic A, Hurdaya R, Nieuwenhuizen NE, Brombacher F, Moll H. Dendritic cell-mediated vaccination relies on interleukin-4 receptor signaling to avoid tissue damage after Leishmania major infection of BALB/c mice. PLoS Negl Trop Dis (2012) 6(7):e1721. doi:10.1371/journal.pntd.0001721

47. Matos I, Mizenina O, Lubkin A, Steinman RM, Idoyaga J. Targeting Leishmania major antigens to dendritic cells in vivo induces protective immunity. PLoS One (2013) 8(6):e67453. doi:10.1371/annotation/5149bf8e-3843-4865a726-0ca2820ee8f8

48. Schwarz T, Remer KA, Nahrendorf W, Masic A, Siewe L, Müller W, et al. T cell-derived IL-10 determines leishmaniasis disease outcome and is suppressed by a dendritic cell based vaccine. PLoS Pathog (2013) 9(6):e1003476. doi:10.1371/ journal.ppat.1003476
Received: 04 February 2014; accepted: 13 February 2014; published online: 26 February 2014

Citation: Freitas-Silva $R$, Brelaz-de-Castro MC and Pereira VR (2014) Dendritic cell-based approaches in the fight against diseases. Front. Immunol. 5:78. doi: 10.3389/fimmu.2014.00078

This article was submitted to Immunotherapies and Vaccines, a section of the journal Frontiers in Immunology. Copyright (C) 2014 Freitas-Silva, Brelaz-de-Castro and Pereira. This is an open-access article distributed under the terms of the Creative Commons Attribution License (CC BY). The use, distribution or reproduction in other forums is permitted, provided the original author(s) or licensor are credited and that the original publication in this journal is cited, in accordance with accepted academic practice. No use, distribution or reproduction is permitted which does not comply with these terms. 